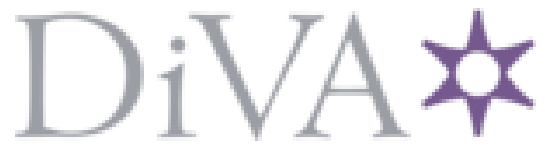

http://www.diva-portal.org

Preprint

This is the submitted version of a paper published in .

Citation for the original published paper (version of record):

Grube, M., Wedin, M. (2016)

Lichenized fungi and the evolution of symbiotic organization.

Microbiology Spectrum, 4(6): FUNK-0011-2016

https://doi.org/10.1128/microbiolspec.FUNK-0011-2016

Access to the published version may require subscription.

N.B. When citing this work, cite the original published paper.

Permanent link to this version:

http://urn.kb.se/resolve?urn=urn:nbn:se:nrm:diva-2029 


\section{Lichenized fungi and the evolution of symbiotic organisation}

2

3

$4 \quad$ Martin Grube ${ }^{1}$ and Mats Wedin ${ }^{2}$

5

$6 \quad{ }^{1}$ Institute of Plant Sciences, University of Graz, Holteigasse 6, 8010 Graz, Austria

$7 \quad{ }^{2}$ Department of Botany, Swedish Museum of Natural History, P.O. Box 50007, 104

805 Stockholm, Sweden.

9

10 Summary. Lichen symbioses comprise a fascinating relationship between algae and

11 fungi. The lichen symbiotic life style evolved early in the evolution of ascomycetes

12 and is also known from a few basidiomycetes. These lineages of ascomycetes have

13 diversified in the lichenized stage to give rise to a tremendous variety of

14 morphologies. Also, their thalli are often internally complex and stratified for

15 optimized integration of algal and fungal metabolisms. Thalli are frequently

16 colonized by specific non-lichenized fungi and occasionally also by other lichens.

17 Microscopy revealed various ways of these fungi to interact with their hosts. Beside

18 the morphologically recognizable diversity of the lichen mycobionts and

19 lichenicolous (lichen-inhabiting) fungi, many other microorganisms including other

20 fungi and bacterial communities are now detected in lichens by culture-dependent

21 and culture-independent approaches. The application of multi-omics approaches,

22 refined microscopic techniques, as well as physiological studies, have added to our

23 knowledge of lichens, not only about the taxa involved in the lichen interactions, but 24 also about their functions. 


\section{Introduction And Historical Background}

Lichens were generally accepted as an independent group of organisms, when Schwendener (1) discovered that lichens are the result of the association of fungi and algae. This insight was not widely accepted by contemporaries, but in fact initiated a scientific revolution as lichens later became the prime example of a mutualistic symbiosis, and indeed the phenomenon for which the term symbiosis was originally introduced in biology [(2) as "Symbiotismus"; (3)]. The lichen symbiosis has proved to be one of the most important life styles in the Ascomycota, and is also known from a few Basidiomycota. Approximately 20000 currently known fungal species live as lichens, mostly in species-rich lineages of Ascomycota (4). The traditional view of lichens as a mutualistic symbiosis of a fungus and one or several green algae or cyanobacteria, has always been under debate (5), but it has recently been more challenged than ever by the discovery of numerous additional microorganisms that potentially occur as obligatory participants in the symbiosis.

The self-supporting associations of fungi and their partners usually form a compact and macroscopically recognizable structure, known as the lichen thallus. Different from many other fungi, which reside beneath the surface of their substrates, the lichen thallus is typically developed at the surface of the substrate or completely exposed to the atmospheric conditions, apparently without exploiting the substrates' nutrients (Fig. 1A-C).

\section{The Lichen Thallus}

The lichen thallus arose early in evolutionary history with the conquest of land, and the earliest records of internally stratified cyanobacterial and green-algal lichens were from the Lower Devonian (6). These lichens are of unclear relationship to 
51 current lichen-forming lineages in the Ascomycota, which originated at least as early as the Carboniferous, and radiated in the Jurassic and Cretaceous to generate the diversity of the main modern groups (7). The ability to revitalize from dry stages helps the lichen thallus in many species to survive environmental fluctuations with extremes of desiccation and temperatures $(8,9)$. Lichens are thus prominent at high altitudes and latitudes where conditions become adverse for most other multicellular organisms. Especially in cool habitats, lichen biomass can be substantial and lichens can then form a substantial part of the vegetation (Fig. 2A-C). By the balance of respiration and photosynthetic energy production in the symbiotic system, many lichen thalli grow slowly but are long-lived. Usually, the fungi dominate biomass and dictate the shape of lichen thalli. The scientific name of lichens also by definition refers to the fungal partner only. peripheral cortex layer (Fig. 3). These layers are developed by the conglutination of fungal hyphae, which seems to be correlated with increased branching and anastomoses formation. The outer walls of the fungi are thickened to form sticky contacts with neighboring hyphae. This appears to be a similar process as found generally with the formation of fungal fruitbodies, but in the case of lichens conglutination and compaction occurs in the vegetative mycelium, and this could be one of the key evolutionary innovations to make lichen thallus evolution possible.

71 The conglutination of vegetative hyphae forms a more or less coherent layer by which algal cells can be covered and under which algal populations can form more or

73 less coherent layers within fungal plectenchyma (i.e., tissue-like structure made of

74 fungal hyphae). This developmental process seems to be correlated with massive branching and anastomosing of the hyphae. While genes regulating branching, 
anastomosing and conglutination are known from model fungal systems, their presence and regulation in lichenized fungi have so far not been studied. The morphogenetic processes seem to be initiated as soon as the fungi contact appropriate algal cells. Once the thallus morphogenesis is initiated, the algal symbionts can proliferate massively under the fungal protectorate. The mycobionts are triggered by the interaction with the algae to produce diverse, more or less complex thallus morphologies, a wide diversity of lichen-derived secondary metabolites, as well as fruitbodies for sexual fungal reproduction and/or asexual structures for combined propagation of symbionts. Notably, strikingly convergent thallus morphologies have evolved in several unrelated lineages of lichenized fungi (10). The convergent shapes include complicated morphologies, for example umbilicate thalli (leafy structures with a central, exclusively fungal holdfast), as well as reductions of complexity, and reversal to simple crustose lichens or even parasitic life-styles, or the formation of thalli composed of grain-like fungal-algal propagules.

In certain lineages, there is a strong selectional trend towards vegetative reproduction solutions that disperse the fungal and algal partners. These include soredia, which are granules of varying size that contain algal cells and fungal hyphae, produced in structures of varying size and morphology termed soralia (Fig. 4A).

Other types of vegetative propagules are corticate, forming easily detached outgrowths from the lichen thallus, called isidia (Fig. 4B). In several lineages of lichens that reproduce by vegetative means, the production of sexual spore-producing structures is rare or unknown.

While most species of lichenized fungi produce highly organized thalli with internal stratification, several "borderline" lichens produce poorly differentiated thalli $(11,12,13)$. A small number of fungal species also seem to be facultatively 
101 lichenized, in the sense that they sometimes are found loosely associated with algae,

102 and sometimes not $(14,15,16)$. In the Stictidaceae, this facultative lichenization is

103 apparently determined by the substrate they grow on, as several species can grow as

104 saprotrophs on dead wood (Fig. 5A) and as loosely lichenized on bark (Fig. 5B). This

105 has been termed "optional lichenization" by Wedin et al. (17). These borderline and

106 optional lichens may be seen as present-day analogs of early thallus evolution, before

107 more advanced forms of thallus organization arose.

108

109 3. The Lichen Fungi And Their Phylogenetic Relationships

110 The integration of lichenized fungi into the classification of Fungi was slow at first

111 as very few lichenologists accepted the consequences of Schwendener's discovery.

112 Vainio (18) was the first to classify at least some higher ranks of the lichen fungi

113 together with other fungi, but the very influential Zahlbruckner $(19,20)$ treated

114 lichens as a separate group, Lichenes, on a level equal to the Ascomycetes and the

115 Basidiomycetes, which prevented further progress for many years. Nannfeldt (21)

116 argued strongly for integrating lichenized fungi into a natural fungal system,

117 something that was acted upon by Santesson $(22,23,24)$. Only in the second half of

118 the $20^{\text {th }}$ century was this integrated classification widely accepted by most

119 mycologists, even if the study of lichen fungi nevertheless often still is considered a

120 matter for lichenologists, and quite distinct from the study of non-lichenized fungi.

121 Lichenized lineages are interesting from a phylogenetic-evolutionary

122 perspective, as they primarily have evolved and diverged in the lichenized condition

123 with similar partners. The self-supporting, self-sufficient lichen thallus is likely to be

124 the target of selective pressures very different from the selective forces working on 
non-lichenized fungi, which creates a substantial difference from what saprobic or parasitic fungi may undergo.

Within the lichens belonging to the Ascomycota, microscopic characters of the sexual reproductive structures, in particular fruit-body development and organization

129 $(25,26,27)$, and ascus structures $(28,29,30)$, helped to refine the taxonomic relationships and were largely the basis of classifications in the late pre-molecular era. Already at that time, there was a vigorous debate about the number of times that the lichen life style arose in the evolution of fungi. Since it was not feasible to grow axenic fungal cultures, it was only possible to amplify mycobiont genes directly from lichen samples after the development of fungal-specific PCR-primers, which excluded the algal partners. With this technical advancement, Gargas et al. (31) were able to provide a first phylogenetic analysis of $18 \mathrm{~S}$ rRNA genes in lichenized fungi. Their results suggested that the lichen life style arose at least twice in the evolution of ascomycetes. Data from more sequences of lichenized lineages were analysed by Lutzoni et al. (32) to revisit the fundamental question of the lichen origins. The idea of two origins was not rejected, but neither was the possibility of a single origin of lichens in Ascomycota. Both studies convincingly showed that the lichen life-style was a rare innovation in the evolution of Ascomycota, while the latter study pointed out that the symbiotic life style was more frequently lost in major ascomycete groups. Later studies (33) again suggest that the lichenization originated multiple times, which seems currently to be the generally agreed view.

During the past years our understanding of the phylogeny within the major lineages of lichenized Ascomycota increased significantly through a number of investigations with large numbers of species. An updated classification of Ascomycota including the lichenized lineages can be found in Jaklitsch et al. (34), 
150 reflecting these discoveries. Extant lichenized fungi occur in at least six of the major

151 lineages within the Ascomycetes; the Arthoniomycetes, Coniocybomycetes,

152 Dothideomycetes, Eurotiomycetes, Lecanoromycetes, and Lichinomycetes (35, 36,

153 37, 38). One additional lichenized lineage may belong to the Leotiomycetes.

154 Different 'relaxed clock' scenarios suggested that the origin and diversification of the

155 Pezizomycotina occurred in the Cambrian (38). Prieto \& Wedin (38) provided

156 information about the timing of the main diversification events in Ascomycota,

157 including estimates for classes, orders and several families of both lichenized and

158 non-lichenized Ascomycota, many of which had not been previously dated. The

159 main lineages of lichen-forming Ascomycota were shown to all have originated at

160 least as early as the Carboniferous, with successive radiations in the Jurassic and

161 Cretaceous generating the diversity of the main modern groups.

162 Comparatively few representatives of Basidiomycota are lichenized, but

163 recently, the Cora-Dictyonema complex was shown to contain a massive number of

164 earlier undistinguished species (39). An investigation focussing on the morphological

165 character evolution in this group showed that the lichenized thallus had evolved

166 progressively from loosely organized filamentous crusts to stereoid and corticioid

167 basidiomata more or less incorporated in the lichenized thallus (40). This indicates

168 that lichenized thalli may have evolved from reproductive structures in their non-

169 lichenized ancestors.

170 In the overview of lichenized Ascomycota below, we select some examples of

171 phylogenetic studies that contribute major advances in our understanding of

172 morphological and chemical character evolution, lichen biology and interactions, or

173 general understanding of major lineages, of each group. 
175 Arthoniomycetes. The Arthoniomycetes contain a single order, Arthoniales, the second-largest group of lichen-forming fungi, which is a morphologically diverse group of predominantly lichenized representatives, where most form lichen symbioses together with green algae of the Trentepohliaceae. Grube (41) presented a pre-molecular era overview of taxonomic and phylogenetic concepts for the Arthoniales. This account provided discussions of selected morphological characters, and a key to the genera now placed in the order. This work served as a baseline for subsequent molecular work. Ertz \& Tehler (42) presented a first comprehensive phylogeny of Arthoniales focusing on lineages previously assigned to Opegraphaceae and Roccellaceae. Their two-locus phylogenetic study showed that traditional morphological characters such as growth form, fruit body type, exciple (a fungal layer of hyphae directly surrounding and derived from the ascoma), hypothecium and ascospores colour, ascospores septation pattern, and secondary metabolism are of limited use in delimiting families and genera. They concluded that the high level of phenotypic plasticity might indicate that the Arthoniales is an old group and that phenotypically characterized genera are paraphyletic. The recent analysis of Frisch et al. (43) focused on the heteromorphic family Arthoniaceae and demonstrated that previous classifications of this family did not reflect evolutionary patterns. According to the phylogenetic hypothesis, lichen secondary metabolites, such as pulvinic acid derivates or red pigments, do not characterize monophyletic groups above the genus level. The study also revealed that lichen-parasitic life style in Arthoniaceae has evolved more than once and is found in four independent lineages of the Arthoniaceae clade and in the Bryostigma clade. Arthoniomycetes with chlorococcoid photobionts are restricted to the Bryostigma clade and Chrysotrichaceae, while the only saprophytic Arthonia species in the phylogeny are 
related to Arthonia radiata and group with lichenized taxa. The phylogenetic data

201 provide a coherent framework for delineating further monophyletic groups in

202 Arthoniaceae in the future.

204 Coniocybomycetes. Coniocybomycetes is a small group (one order and family, currently two genera with ca. 30 species) of crustose lichens with prototunicate (thinwalled and evanescent) asci and mazaedia-producing (mazaedium - an accumulation of loose, maturing spores covering the ascoma surface), stalked ascomata. This is the most recently described class of Ascomycota and is apparently related to the Lichinomycetes (38), butthis relationship is not supported by any obvious morphological characteristics. The Coniocybomycetes is one of the few lichen

211 groups from which a fossil is known, which Prieto \& Wedin (7) also utilized in their 212 dating of the major groups of Ascomycota.

214 Dothideomycetes. The Dothideomycetes is a very large fungal group characterized 215 by ascolocular ascoma development, and only some representatives are lichenized. A comprehensive phylogenetic study of representatives of 41 families using sequences

217 from five genes was presented by Schoch et al. (44). Notably, the ancestral 218 reconstruction of basic nutritional modes suggests numerous transitions from 219 saprobic life histories to either plant-associated or lichenised modes. Nelsen et al. 220 (37) integrated the primarily lichen-forming families Trypetheliaceae, 221 Monoblastiaceae and Arthopyreniaceae in a phylogeny of Dothideomycetes. Perez222 Ortega et al. (13) introduced the new order Collemopsidiales, which contains 223 Xanthopyreniaceae, an interesting family including borderline lichens, many of 224 which occur in rocky intertidal habitats, as well as lichenicolous fungi. 
226 Eurotiomycetes. Eurotiomycetes is likewise a very large and morphologically

227 heterogenous group where only some representatives are lichenized, all within the

228 subclass Chaetothyriomycetidae, which is an assemblage of ecologically diverse

229 species, ranging from mutualistic lichenised fungi to human opportunistic pathogens.

230 A multigene phylogenetic study of rock-dwelling fungi concentrating on the

231 Verrucariales suggested that this lichenized order as one of the independent

232 ascomycete groups where lichenisation has evolved on a hostile rock surface (45).

233 The delimitation of orders and families in Chaetothyriomycetidae was re-assessed by

234 Gueidan et al. (35) in a broad phylogenetic study which classified four orders and ten

235 families in Chaetothyriomycetidae.

237 Lecanoromycetes. This class comprises the largest group of lichenized fungi and

238 one of the most species-rich classes in the kingdom of Fungi. Traditional concepts of

239 classification included reproductive structures, in particular of ascomata and ascus

240 apex structure (which often contain characteristic amyloid features). These

241 traditional concepts were challenged when comprehensive sequence sampling of taxa

242 was available $(46,47,48)$. Miadlikowska et al. (49) demonstrated that the

243 Acarosporomycetidae and Ostropomycetidae are monophyletic subclasses, whereas

244 the delimitation of the largest subclass, the Lecanoromycetidae, remained uncertain.

245 This and the previous phylogenies confirmed that ascus apex morphology cannot be

246 consistently used as a cardinal character for family level classification of lichen-

247 forming fungi (50).

248 One important approach in understanding the evolution of phenetic features of

249 lichens is by studying large genera, which are pragmatically circumscribed by key 
characters. In many studies these key characters proved to be misleading, and rather

251 were symptoms of massively parallel evolution and thus produced by unrelated

252 fungi. Examples of such misleading key characters are prototunicate asci and

253 mazaedia, which used to characterize the "old" order Caliciales (including pin- and

254 stubble-lichens), a group that in its "old" circumscription now has been shown to be 255 extremely polyphyletic $(51,38)$ and where the families Caliciaceae and

256 Sphaerophoraceae are now classified in the Lecanoromycetes $(31,38)$. Another

257 example of this phenomenon was provided by Schmull's et al. (52) analysis of the

258 heterogenous Lecidea (containing 1200 species), which are usually characterized by

259 black fruitbodies on a crust-like thalli and single-celled, hyaline ascospores. As

260 expected, the analysed species of Lecidea sensu lato and putatively related taxa were

261 scattered within Lecanoromycetidae, and some were even placed outside currently

262 recognized orders in Lecanoromycetidae.

263 Most of the lichen fungi that form symbioses with filamentous Nostoc

264 cyanobacteria belong to the Lecanoromycetes. Nostoc has a sheath around the

265 filamentous thread-like colonies that swells and becomes extremely gelatinous when

266 wet and this gives many cyanolichens a gelatinous habit when moist. Within the

267 Lecanoromycetes, most gelatinous lichens are classified in the Collemataceae. This

268 is yet another example of how classifications have been based on misleading key

269 characters as a number of gelatinous, Nostoc-containing groups formerly placed in

270 Collemataceae are nested within another Peltigerales family, the Pannariaceae (53,

271 54). Symbioses with Nostoc have clearly arisen several times. Depending on the

272 reconstruction method, most or all transformations in thallus structure within

273 Peltigerales took place from a non-gelatinous to a gelatinous, Nostoc-containing

274 thallus (53). 
Within Lecanorales, the phylogeny of the largest lichen family Parmeliaceae was studied in a number of papers, where Crespo et al. (55) showed that morphological characters discriminated the main clades well, but that the interpretation of the morphological diversity had been quite superficial. The morphological diversity was indeed found to be substantial in this family when Divakar et al. (56) showed that the lichenicolous lifestyle originated independently three times within Parmeliaceae, ca. 24 million years ago.

Gaya et al (57) studied the Teloschistales using a supermatrix approach and showed that a progressive, cumulative, addition of taxa to the matrix analysed with a resulting increasing amount of missing data, did not affect the support and resolution much, but that the monophyly of the order was inconsistent depending on the combination of loci and taxa. In the Teloschistaceae, Arup et al. (58) proposed a completely re-organized generic classification, and investigated how the apparently large morphological plasticity affected the characterization of genera and species. Secondary metabolites were frequently found to better serve as characterizing traits than morphology, at least in parts of the family.

Within Ostropomycetidae Baloch et al. (59) suggested that the evolution of life-styles and ascomatal morphologies in this group was very plastic, as shown by the multiple evolution of perithecioid ascomata in the Gyalectaceae. Early evolutionary splits in the Ostropomycetidae, in fact the second-most species-rich subclass of lichenized Ascomycota, were considered by Resl et al. (60) in their analysis of trapelioid fungi. The uncertain phylogenetic resolution of the c. 170 species prevented a clear backbone concept for the subclass. A monophyletic group of nine core trapelioid genera was found, which do not form the sister group of Ostropales, but the hypothesis of a sister group relationship of trapelioid genera and 
300 Baeomycetaceae or Hymeneliaceae could not be rejected. Recently, Miadlikowska et

301 al. (61) provided the most comprehensive phylogenetic survey of the entire

302 Lecanoromycetes using a multigene maximum likelihood analysis with a cumulative

303 supermatrix approach. However the analysis of this massive data set (1139 taxa)

304 revealed that the cumulative addition of taxa with an increasing amount of missing

305 data leads to relatively stable representation of relationships for many families and

306 orders, but also in substantial loss of phylogenetic resolving power and support for

307 deep phylogenetic relationships.

308 In the Graphidaceae, a very large family of >2000 species, Lumbsch et al. (62)

309 studied character evolution and found that certain characters (secondary metabolites,

310 in particular) had a high frequency of reversible phenotypic state changes, whereas

311 others, such as photobiont, hymenial persistence or ascoma aggregation, exhibited

312 low frequency of transformations. But even in the character with the highest number

313 of state changes (changes in secondary metabolite composition), the shifts were

314 highly structured phylogenetically, suggesting that the evolution of the character,

315 rather than the character state itself, can be used to predict phylogenetic relationships

316 with certain accuracy.

318 Leotiomycetes. Trizodia acrobia is a borderline lichen and the sister group of

319 Leotiomycetes. The lineage was discovered by Stenroos et al. (63) in a phylogenetic

320 analysis of bryophilous ascomycetes. Trizodia is ecologically unique by its

321 association with cyanobacterial colonies (mostly Nostoc) growing on the tips of peat

322 mosses (Sphagnum spp.). Trizodia was consistently present in all Sphagnum-Nostoc

323 associations studied. It envelops the cyanobacterial colonies both on the moss surface

324 as well as inside the leaf but does not form organized thallus structures. 


\section{The Upcoming Genomics Perspective For Understanding Lichen Symbioses}

327 Increasing the number of loci used to determine phylogenetic relationships is now

328 possible through characterization of entire genomes of lichens. Genome-scale

329 datasets may lead to the development of consistent, well-supported hypotheses about

330 the evolution of lichenized fungi. A first step towards a phylogenomic analysis of

331 lichen-forming fungi was undertaken in an exemplary phylogenomic study of the

332 genus Rhizoplaca (Lecanoromycetes) by Leavitt et al. (64).

333 Current high-throughput sequencing technology has opened new opportunities

334 for studying organisms that grow slowly and are difficult to establish and grow in

335 axenic cultures. These difficulties explain why comparative genomics of lichen fungi

336 lags behind the advances made so far in other fungal groups. Meanwhile, genetic

337 manipulation, such as transformation, of lichens has been attempted (65). Numerous

338 lichen genome projects have been started in the past years, and some preliminary data

339 are already available. Basically, two strategies are followed in lichen genomics. The

340 more traditional approach is the acquisition of genetic information from the

341 individually cultured symbiotic partners. With the alternative metagenomic approach

342 the total symbiotic association is first sequenced and the genetic information is

343 afterwards assigned to symbiotic partners by bioinformatic analysis. Such progress is

344 possible by exploiting technologies that have significantly improved the quality of

345 sequence assemblies (e.g., by “mate-pair” sequencing) and by powerful

346 bioinformatics pipelines. Apart from gaining information on basic genomic features

347 such as genome size and predicted numbers of genes (Tab. 1), several studies

348 provided more detailed analyses of interesting functions. 
Some of these analyses focused on the biosynthetic pathways of secondary metabolites of lichenized fungi (including depsides and depsidones, as classes of

351 coupled phenol carboxylic acids). Sequencing the $34 \mathrm{Mb}$ genome of the Cladonia 352 grayi mycobiont revealed new insights in the production of the lichen depsidone 353 grayanic acid (66), and suggests that a single polyketide synthase (PKS) synthesizes 354 two aromatic rings on tandem acyl carrier proteins and links them into a depside, and 355 that the transition from depside to depsidone requires only a cytochrome P-450 mono356 oxygenase. Sequencing of the Cladonia uncialis mycobiont revealed a putative 357 biosynthetic gene cluster leading to usnic acid, a dibenzofuran derivative (67). 358 Although no typically crystallized lichen substances have been recorded for $P$. 359 membranacea, a large number of mycobiont and photobiont genes and gene clusters 360 associated with secondary metabolite biosynthetic pathways have been identified in 361 its metagenome, and an unusual trans-AT polyketide biosynthetic pathway of a type 362 known only from other bacterial-eukaryote symbiosis has been identified in the 363 Nostoc photobiont (68).

364 In addition, the genome sequencing provided evidence that the tight 365 association of fungi and prokaryotes might have favored horizontal gene transfer 366 (HGT) events. One such event was detected in the methylammonium permease family 367 between prokaryotes and the Cladonia grayi mycobiont (69). Subsequently 368 McDonald et al. (70) suggested that lichen-forming fungi are losing this gene family 369 at slower rate than other fungal lineages.

370 The integration of further available (meta)omics approaches, such as 371 (meta)transcriptomics or (meta)proteomics, provides new and complementary insights 372 into the lichen symbiosis. In this context, transcriptomics reveals which of the total set 373 of genes are activated under certain conditions, whereas proteomics suggests which 
374 functions are actually translated into protein functions. An initial full-length cDNA

375 library as a reflection of the transcriptome was provided by Wang et al. (71), using the

376 cultured mycobiont of the desert lichen Endocarpon pusillum. However, because a

377 symbiotic context is missing, the significance of the detected gene expression for

378 symbiosis is unclear. In a subsequent study of the same lichen, Wang et al. (72) also

379 analysed dehydrated thalli and confirmed expression of 23 candidate stress responsive

380 genes, selected from a larger set found with mycobiont cultures exposed to PEG-

381 induced drought stress. There is also ongoing RNA-Seq work aiming to compare gene

382 expression in the mycobiont alone in pure culture versus the mycobiont in the

383 symbiotic state to identify genes that are differentially expressed and might therefore

384 be correlated with symbiotic interactions. Gene expression studies elucidate relative

385 levels of active genes (73). Also, epigenetic modifications such as the presence of 5-

386 methycytosine in lichen genomes can be determined in conjunction with next-

387 generation sequencing platforms.

388 Moving a step further, Juntilla and Rudd (74) used high-throughput next

389 generation sequencing and expressed sequence tag (EST) sequence data to present a

390 first transcriptome of the eukaryotic partners in the thalli of the reindeer lichen

391 Cladonia rangiferina (with $62.8 \%$ reads of fungal and $37.2 \%$ of algal origin). Even

392 though a higher percentage of algal reads was found in the wetted thalli used, gene

393 ontology (GO) terms (http://geneontology.org/) and identified KEGG pathways

394 (www.genome.jp/kegg/) largely agreed with eukaryotic metaproteome patterns found

395 by Schneider et al. (75). Juntilla et al. (76) tracked the expression profiles during

396 dessiccation and rehydration using microarray analyses, but the data do not provide

397 detailed insights into the regulatory processes. Most of the differentially expressed 
genes do not show sequence similarity to known genes. It is, however, remarkable that largest changes of gene expression are observed only minutes after rehydration. contributions of genes are organ-specific and modified by pertinent ecological and

402 developmental conditions. The partially annotated Peltigera membranacea

403 metagenome revealed the presence of mycobiont genes encoding galectin-like 404 proteins, which are family of proteins defined by their binding specificity for $\beta$ 405 galactoside sugars (77). RNA-Seq data further showed that one of these genes, lec-1, 406 was differentially expressed in rhizines, a purely fungal tissue, when compared to the 407 remainder thallus, composed of both mycobiont and photobiont (73). While forthcoming comparative genomics studies will inform us about the evolutionary dynamics of lineages diverging in lichen-symbiotic stages,

410 transcriptomics, proteomics, and metabolomics will improve our understanding of the 411 symbiotic regulation and processing. Lobaria pulmonaria, a tripartite lichen

412 (including both a green algae and a cyanobacterium) widely distributed in the

413 Northern hemisphere, has been featured in publications that have explored 414 metaproteomic issues $(75,78)$. Most algal proteins were assigned to energy 415 production and conversion. Carbohydrate transport and metabolism were significant 416 in both eukaryotic partners, but fungal functions were more diverse, with substantial 417 read numbers suggesting biogenesis and posttranslational modification. The bacterial 418 fraction (see also further below) in the metaproteome was dominated by proteins from 419 Alphaproteobacteria. The identified proteins are primarily involved in energy 420 conversion and carbohydrate metabolism, as well as responses to stress. Also, some of 421 the bacterial proteome spectra suggested a role of bacteria in secondary metabolite 422 synthesis, but this could not be resolved in full detail so far. 
424 5. Fungal-Algal Connections And Interactions In The Thallus.

425 The main role of the algal partners is the provision of photosynthetically fixed 426 carbohydrates as the energetic basis for the self-sustained life style. The lichen427 forming fungi take up osmotically active monomeric sugars from the algae, which are 428 then further metabolized. Typically, green algae supply polyols (ribitol in 429 chlorococcal algae and erythritol in filamentous Trentepohliales), whereas glucose is 430 provided by cyanobacterial algae. Apparently the process of lichenization also 431 stimulates upregulation of photo-protective mechanisms in the photobiont (79). In 432 turn, the photobiont stimulates the antioxidant system of the mycobiont $(8,9)$.

433 Currently it is not well known, which chemical signals are transferred during the 434 initiation and onset of lichenized stages, and what effects they have in the symbiosis. 435 By comparison of algal strains, Meeßen and Ott (80) detected characteristic 436 metabolites in lichen-forming algae, such as the cyclic dipeptides cyclo-L-leucyl-L437 tyrosine and cyclo-(L-tryptophyl-L-tryptophyl), rhamnose and indole-3-carbaldehyde, 438 a precursor or a degradation product of the phytohormone indole-3-acetic-acid. 439 Because hyphal branching is not stimulated with these substances alone, but when 440 unicellular algae grow in proximity (81), further metabolites seem to be involved in 441 the signalling of lichenization. Such molecules probably include phytohormones 442 abscisic acid and ethylene, as well as others $(82,83,84)$.

443 The fungal partner frequently produces attachment or penetration structures 444 (appressoria or haustoria, respectively) of different kinds at the mycobiont-photobiont 445 interface. Water and dissolved nutrients are can move readily between the bionts at 446 the contact zone, within a hydrophobic coat that the fungus produces over the algal 447 cell surface $(85,86)$. 
Lichen fungi associate with only about 120 known species of algae, most of

449 them green algae, and a few cyanobacterial algae (86), although the species taxonomy

450 is so poorly understood in lichenized cyanobacteria that these currently cannot be

451 identified to species level (87). The photosynthetic partners are green algae in about

$45290 \%$ of lichen species. Hence $10 \%$ of the lichens take advantage of bacterial nitrogen

453 fixation and associate with cyanobacterial algae, most commonly with filamentous

454 Nostoc strains. Another strategy is the additional association with Nostoc strains in

455 specialized organs (cephalodia; Fig. 6A) in or on a green-algal thallus (88), resulting

456 in tripartite lichens, which apparently evolved as a segregation of functions. The

457 higher proportion of heterocysts suggests a main role of cephalodia in nitrogen

458 fixation (89). On the other hand, several cyanobacterial lichens may also have green

459 algae in addition to the cyanobacteria in their photosynthethic layer (90), which might

460 widen their ecological amplitude in cool habitats. Few fungal species are even able to

461 use either eukaryotic green or prokaryotic blue-green algae to develop independent

462 symbiotic thalli (91). These phycosymbiodemes, primarily found in the order

463 Peltigerales of Lecanoromycetes either have similar morphologies, or are shaped

464 profoundly differently (Fig. 6B). When growing separately they were described in

465 independent genera, which obviously has blurred the understanding of their

466 phylogenetic relationships (92).

467 With very few exceptions, the green algae propagate clonally and do not form

468 sexual structures in the lichenized stage. The apparent suppression of the sexual

469 capacity of the algal partner by the lichen-forming fungi could be interpreted as a

470 selfish strategy to avoid genetic diversification of the partner and to maintain

471 efficient control over the algal physiology. 

about lichen photobiont diversity as well, both their phylogenetic relationship as well as their patterns of association with their fungal hosts. Major mycobiont lineages seem to vary by their overall spectra of preferences for algal groups. While the majority of Arthoniomycetes have a preference for Trentepohliaceae (except for some species assigned to Arthonia), Lecanoromycetes and particulary members of Chaetothyriomycetes (above all Verrucariales) associate with a broader range of green algae $(43,61,93)$.

Recent work suggests that species of lichenized fungi frequently vary in their algal specificity and selectivity. This correlates with the range of the species and climatic differences, i.e. the same lichens occurring in different habitats often associate with related algal species with different ecological preferences $(94,95)$. This flexibility supports the hypothesis of habitat-adapted symbioses proposed by Rodriguez et al. (96) which suggests that the environment determines the optimal partnership of symbionts. Wedin et al. (97) showed that Diploschistes muscorum has an even more flexible photobiont strategy than earlier believed. Diploschistes starts as a parasitic fungus infecting the unrelated lichen Cladonia (Fig. 7), eventually taking over and forming an independent thallus. Although the Cladonia used the same photobiont at all investigated sites, Diploschistes associated with different photobionts at all three sites, keeping the original Cladonia alga at one site but replacing it with others in the two other sites (97). This suggests a very generalistic 493 photobiont strategy in this lichenicolous (=lichen-inhabiting) lichen. Rikkinen et al. (98) suggested that lichen fungi in the Peltigerales form ecological photobiont guilds, within which the fungi share related photobiont cyanobacteria. Such associations can be seen both among an ecological assemblage 
of epiphytic macrolichens, the Nephroma-guild, and among a group of predominantly terricolous cyanolichens, the Peltigera-guild, where the photobionts with each guild are closely related Nostoc-strains. Several authors have likewise observed similar photobiont-mediated guilds in green-algal lichens $(99,5)$.

\section{Additional Fungi In The Lichen Symbiosis}

As lichen thalli are very persistent and variable morphologically, they provide a rich diversity of small-scale niches for various microorganisms, in particular fungi and bacteria (treated below). Lichenicolous (lichen-inhabiting) fungi comprise all fungal species living in or on lichens, apart from the thallus-forming fungus itself (the mycobiont). This biological group has been studied extensively, and was even recognized before the symbiotic nature of their lichen hosts was established. More than 1,800 species of lichenicolous fungi have been described (100), but as numerous new species are still being discovered, their precise number is unknown but is clearly

511 currently much underestimated. The evolutionary origin of the lichenicolous life

512 style is diverse, but a substantial number of lichenicolous fungi apparently evolved 513 after delichenization of originally lichenized lineages. As most lichenicolous fungi 514 seem to exploit their hosts without rapid destruction, they are highly specific for their 515 hosts, and for particular symbionts of the hosts. Typically lichenicolous fungi are recognizable by conspicuous reproductive

517 structures or by their symptoms such as discolorations or gall-like 518 hypertrophications. Some other species associate with lichens but remain cryptic. 519 Isolation techniques and axenic cultivation revealed that these species either reside 520 on the surfaces of the thalli $(101,102,103)$, or occur internally in lichen host thalli 521 (also known as "endolichenic fungi", 104). Given the abundance and the potential of 
522 culturable endolichenic fungi to produce secondary metabolites, it might be argued

523 whether these fungi might have a biological effect on their host, or influence the

524 phenotype in various ways. However, even though microscopic evidence already

525 demonstrates the endolichenic growth of fungi beside the mycobiont in lichens (86),

526 it is not clear which of these fungi grow in lichens or reside as spores or otherwise in

527 dormant stages.

528 Culture techniques have retrieved a surprisingly large number of fungal species

529 from lichens (105), but these numbers only represents a subset of the total fungal

530 diversity present in environmental samples. Therefore, culture-independent methods

531 are now also employed to characterize the mycobiome of lichen thalli. Using DNA-

532 fingerprinting techniques, Fleischhacker et al. (106) found a high diversity of lichen-

533 associated fungi without correlation with the presence of externally visible

534 lichenicolous fungi. Zhang et al. (107) provided an overview of diversity and

535 distribution of fungi in lichens from an Arctic habitat using next generation

536 sequencing. Their study of the lichen mycobiome indicated that lichens harbor fungi

537 related to those with diverse ecological context. Lichens thus represent a reservoir or

538 an evolutionary hotbed for fungi that may have a role in other habitats, but the

539 specific conditions in fungi with recurrent and prolonged cryptobiotic stages do not

540 favor the rise of, for example, a biotrophic plant pathogen. Studies in Lobaria

541 revealed the high specificity of Tremella lobariacearum (108), but whether the same

542 is true for non-symptomatic occurrences of Tremellomycetes is unknown. Refined

543 microscopic techniques can reveal to what extent the scattered occurrence of

544 tremellalean fungi might influence the morphology of the host. Millanes et al. (109)

545 described Cystobasidiomycetes as a new lineage of Pucciniomycotina. The 
546 lichenicolous members of this lineage, which primarily comprises yeasts, cause

547 conspicuous fertile hypertrophications of their hosts.

\section{Bacterial Participation In Lichen Thalli}

550 Fungi associated with lichens have been studied extensively for a long time, but the

551 ubiquitous presence of bacteria in lichen thalli received more attention only comparatively recently. Sequencing of lichen-associated bacterial communities revealed information about their diversity on lichen thalli $(110,111,112,113,114$, $115,116,117,118)$. Alphaproteobacteria usually dominate the bacterial communities in lichens, while other bacterial groups (frequently Acidobacteria, Actinobacteria, and Betaproteobacteria) are also found in significant numbers. One group of Alphaproteobacteria, the lichen-associated Rhizobiales (LAR1) is a clade of bacteria so far known only from lichens $(113 ; 115)$. Sequence-based data are complemented with microscopic information, in particular employing fluorescence in situ hybridization (FISH)(119). The distribution of bacteria belonging to certain groups

561 can be visualized under the microscope using specific probes (confocal laser scanning microscopy, CLSM). Bacteria often form biofilm-like communities on the lichen thalli and are usually tightly connected with the fungal structures, in particular

564 with hydrophilic surfaces of the lichens. The bacteria can also intrude to various

565 depths in the intercellular matrix of the upper cortex, and are occasionally also found 566 inside the hyphae of the fungal hosts (120). The lichen-associated bacterial 567 communities so far investigated are host-specific in their composition $(112 ; 115)$. A 568 clear shift is microbiome profile is observed when the parasitic lichen Diploschistes 569 muscorum infects, and eventually overcomes Cladonia symphycarpa, to form a 570 thallus of its own (97; Fig. 7). Here, the Alphaproteobacteria population dominating 
571 the Cladonia microbial community decreases during the transition, and numbers of

572 Betaproteobacteria or Chloroflexi increase substantially when Diploschistes takes

573 over, supporting the view that the microbial community is highly species-specific in

574 lichen thalli.

575

576 Conclusions

577 Phylogenetic studies significantly improved the understanding of evolution and

578 phenotypic diversification of lichenized fungi and their partners. Lichen thalli are

579 dominated by the primary fungal symbiont, which controls the characteristic

580 photosynthetic partners. Beside these commonly known symbionts, an unknown

581 numbers of additional organisms can participate in the symbiont system (121). The

582 analysis of massive amounts of molecular data from lichens, which has just started,

583 will help to further understand the role of these complex and fascinating partnerships.

585 References

586 1. Schwendener S. 1869. Die Algentypen der Flechtengonidien. Basel.

587 2. Frank AB. 1877. Über die biologischen Verhältnisse des Thallus einiger

588 Krustenflechten. Cohn, Beiträge zur Biologie der Pflanzen 2:123-200.

589 3. de Bary A. 1879. Die Erscheinung der Symbiose. Strasburg.

590 4. Sipman HJM, Aptroot A. 2001. Where are the missing lichens? Mycol Res

$591 \quad$ 105:1433-1439.

592 5. Piercey-Normore MD, Deduke C. 2011. Fungal farmers or algal escorts: lichen

593 adaptation from the algal perspective. Molecular Ecology 20:3708-3710. 
6. Honegger R, Edwards D, Axe L. 2013. The earliest records of internally stratified cyanobacterial and algal lichens from the Lower Devonian of the Welsh Borderland. New Phytologist 197:264-275.

7. Prieto M, Wedin M. 2013. Dating the diversification of the major lineages of Ascomycota (Fungi). PLoS One 8(6): e65576..

8. Kranner I, Cram JW, Zorn M et al. 2005. Antioxidants and photoprotection in a 600 lichen as compared with its isolated symbiotic partners. Proc Natl Acad Sci USA 102:3141-3146.

9. Kranner I, Beckett RP, Hochman A, Nash TH III. 2008. Desiccation tolerance in lichens: a review. Bryologist 111:576-593.

10. Grube M, Hawksworth DL. 2007. Trouble with lichen: the re-evaluation and reinterpretation of thallus form and fruit body types in the molecular era. Mycological Research 111:1116-1132.

11. Kohlmeyer J, Hawksworth DL, Volkmann-Kohlmeyer B. 2004. Observations on two marine and maritime "borderline" lichens: Mastodia tessellata and Collemopsidium pelvetiae. Mycological Progress 3:51-56.

12. Muggia L, Gueidan C, Knudsen K, Perlmutter G, Grube M. 2013. The lichen connections of black fungi. Mycopathologia 175:523-535.

613 Hidden diversity of marine borderline lichens and a new order of fungi:

614 Collemopsidiales (Dothideomyceta). Fungal Diversity in press.

615 14. Hawksworth DL. 1988. The variety of fungal-algal symbioses, their

616 evolutionary significance, and the nature of lichens. Botanical Journal of the

617 Linnean Society 96:3-20. 
618 15. Aptroot A. 1991. A monograph of the Pyrenulaceae (excluding Anthracothecium 619 and Pyrenula) and the Requienellaceae, with notes on the Pleomassariaceae, the

620 Trypetheliaceae and Mycomicrothelia (lichenized and non-lichenized

621 Ascomycetes). Bibliotheca Lichenologica 44:1-178.

622 16. Aguirre-Hudson B. 1991. A taxonomic study of the species referred to the 623 ascomycete genus Leptorhaphis. Bulletin of the British Museum (Natural History), Botany 21:85-192.

17. Wedin M, Döring H, Gilenstam G. 2004. Saprotrophy and lichenization as options for the same fungal species on different substrata: environmental plasticity and fungal lifestyles in the Stictis-Conotrema complex. New Phytologist 164:459465.

18. Vainio EA. 1890. Étude sur classification naturelle et morphologie des lichens du Brésil. Acta Societatis pro Fauna et Flora Fennica, Helsinki 7:1-256.

19. Zahlbruckner A. 1907. Lichenes (Flechten) B. Spezieller Teil, p 49-249. In Engler A, Prantl K (ed), Die natürlichen Pflanzenfamilien. 1.Teil, Leipzig.

20. Zahlbruckner A. 1926. Lichenes (Flechten) B. Spezieller Teil, p 61-270. In Engler A, Prantl K (ed), Die natürlichen Pflanzenfamilien. 2.Auflage, Vol. 8, Leipzig.

21. Nannfeldt JA. 1932. Studien über die Morphologie und Systematik der nichtlichenisierten inoperculaten Discomyceten. Nov Act Reg Soc Upsal 8:1-368.

22. Santesson R. 1952. Foliicolous lichens I. A revision of the taxonomy of the obligately foliicolous, lichenized fungi. Symbolae Bot Upsal 12:1-590.

23. Santesson R. 1953. The new systematics of lichenized fungi, p 809-810. In 
24. Santesson R. 1954. Fungal symbionts of lichens. Taxon 3:147-148.

25. Henssen A, Jahns M. 1974. Lichenes. Eine Einführung in die Flechtenkunde. Stuttgart: G. Thieme.

26. Henssen A, Keuck G, Renner B, Vobis G. 1981. The lecanoralean centrum, p 138-234. In Reynolds DR (ed.), Ascomycete Systematics. The Luttrellian Concept. Springer-Verlag, New York, Heidelberg, Berlin.

27. Döring H, Lumbsch HT. 1998. Ascoma ontogeny: is this character set of any use in the systematics of lichenized ascomycetes. Lichenologist 30:489-500.

28. Hafellner J. 1984. Studien in Richtung einer natürlicheren Gliederung der Sammelfamilien Lecanoraceae und Lecideaceae. Beitrage zur Lichenologie. Festschrift J. Poelt. Beihefte zur Nova Hedwigia, 79:241-371.

29. Rambold G, Triebel D. 1992. The inter-lecanoralean associations. Bibliotheca lichenologica 48:1-201.

30. Hafellner J, Hertel H, Rambold G, Timdal E. 1993. A new outline of the Lecanorales. Graz: Privately published by the authors.

31. Gargas A, DePriest PT, Grube M, Tehler A. 1995. Multiple origins of lichen symbioses in fungi suggested by SSU rDNA phylogeny. Science 268:1492-1495.

32. Lutzoni, F., Pagel, M., Reeb, V. 2001. Major fungal lineages are derived from lichen symbiotic ancestors. Nature 411:937-940.

\section{Schoch CL, Sung GH, López-Giráldez F, Townsend JP, Miadlikowska J,} Hofstetter V, Robbertse B, Matheny B, Kauff F, Wang Z, Gueidan C, Andrie RM, Trippe K, Ciufetti LM, Wynns A, Fraker E, Hodkinson BP, Bonito G, Groenewald JZ, Arzanlou M, De Hoog GS, Crous PW, Hewitt D, Pfister D, Peterson K, Gryzenhout M, Wingfield MJ, Aptroot A, Suh SO, Blackwell M, Hillis DM, Griffith GW, Castlebury LA, Rossman A, Lumbsch HT, Lücking 

evolution of fundamental reproductive and ecological traits. Systematic Biology 58:224-239.

34. Jaklitsch W, Baral HO, Lücking R, Lumbsch HT. 2016. Syllabus of plant families. Part 1/2 Ascomycota. Borntraeger Science Publishers, Stuttgart.

35. Gueidan C, Aptroot A, Da Silva ME, Cáceres Badali H, Stenroos S. 2014. A reappraisal of orders and families within the subclass Chaetothyriomycetidae (Eurotiomycetes, Ascomycota). Mycological Progress 13:1027-1039.

36. James TY, Kauff F, Schoch C, Matheny PB, Hofstetter V, Cox C J, Celio G, Gueidan C, Fraker E, Miadlikowska J, Lumbsch HT, Rauhut A, Reeb V, Arnold AE, Amtoft A, Stajich JE, Hosaka K, Sung GH, Johnson D, O'Rourke B, Crockett M, Binder M, Curtis JM, Slot JC, Wang Z, Wilson AW, Schüßler A, Longcore JE, O'Donnell K, Mozley-Standridge S, Porter D, Volkmann-Kohlmeyer B, Spotts RA, Serdani M, Crous PW, Hughes KW, Matsura K, Langer E, Lanfer G, Untereiner WA, Lücking R, Büdel B, Geiser DM, Aptroot A, Diederich P, Schmitt I, Schultz M, Yahr R, Hibbett DS, Lutzoni F, McLaughlin DJ, Spatafora JW and Vilgalys R. 2006. 
Reconstructing the early evolution of fungi using a six-gene phylogeny. Nature 443:818-822.

695

696

697

698

699

700

701

702

703

704

705

706

707

708

709

710

711

712

713

714

715

716

717

37. Nelsen MP, Lücking R, Mbatchou JS, Andrew CJ, Spielmann AA, Lumbsch HT. 2011. New insights into relationships of lichen-forming Dothideomycetes. Fungal Diversity 51:155-162.

38. Prieto M, Baloch E, Tehler A, Wedin M. 2013. Mazaedium evolution in the Ascomycota (Fungi) and the classification of mazaediate groups of unclear relationship. Cladistics 29:296-308.

39. Lücking R, Dal-Forno M, Sikaroodi M, Gillevet PM, Bungartz F, Moncada B, Yánez-Ayabaca A, Chaves JL, Coca LF, Lawrey JD. 2014. A single macrolichen constitutes hundreds of unrecognized species. Proceedings of the National Academy of Sciences U.S.A. 111:11091-11096.

40. Dal-Forno M, Lawrey JD, Sikaroodi M, Bhattarai S, Gillevet PM, Sulzbacher M, Lücking R. 2013. Starting from scratch: Evolution of the lichen thallus in the basidiolichen Dictyonema (Agaricales: Hygrophoraceae). Fungal Biology 117:584-598.

41. Grube M. 1998. Classification and phylogeny in the Arthoniales (lichenized Ascomycetes). The Bryologist 101: 377-391.

42. Ertz D, Tehler A. 2011. The phylogeny of Arthoniales (Pezizomycotina) inferred from nucLSU and RPB2 sequences. Fungal Diversity 49:47-71.

43. Frisch A, Thor G, Ertz D, Grube M. 2014. The Arthonialean challenge: restructuring Arthoniaceae. Taxon 63:727-744.

44. Schoch CL, Crous PW, Groenewald JZ, Boehm EWA, Burgess TI, de Gruyter J, de Hoog GS, Dixon LJ, Grube M, Gueidan C, Harada Y, Hatakeyama S, Hirayama K, Hosoya T, Huhndorf SM, Hyde KD, Jones 

Mbatchou JS, McVay AH, Miller AN, Mugambi GK, Muggia L, Nelsen MP, Nelson P, Owensby CA, Phillips AJL, Phongpaichit S, Pointing SB, Pujade-

45. Gueidan C, Villaseñor CR, de Hoog GS, Gorbushina AA, Untereiner WA and Lutzoni F. 2008. A rock-inhabiting ancestor for mutualistic and pathogenrich fungal lineages. Studies in Mycology 61:111-119.

46. Lumbsch HT, Schmitt I, Palice Z, Wiklund E, Ekman S, Wedin M. 2004.

Supraordinal phylogenetic relationships of Lecanoromycetes based on a Bayesian analysis of combined nuclear and mitochondrial sequences. Molecular Phylogenetics and Evolution 31:822-832.

47. Wedin M, Wiklund E, Crewe A, Döring H, Ekman S, Nyberg Å, Schmitt I, Lumbsch HT. 2005. Phylogenetic relationships of Lecanoromycetes (Ascomycota) as revealed by analyses of mtSSU and nLSU rDNA sequence data. Mycological Research 109:159-172.

48. Ekman S, Andersen H L, Wedin M. 2008. The limitations of ancestral state reconstruction and the evolution of the ascus in the Lecanorales (lichenized Ascomycota). Systematic Biology 57:141-156.

49. Miadlikowska J, Kauff F, Hofstetter V, Fraker E, Grube M, Hafellner J, Reeb V, Hodkinson BP, Kukwa M, Lücking R, Hestmark G, Otalora MG, Rauhut A, Büdel B, Scheidegger C, Timdal E, Stenroos S, Brodo IM, 
50. Tibell, L. 1998. Practice and prejudice in lichen classification. Lichenologist 30:439-453.

51. Tibell L. 1984. A reappraisal of the taxonomy of Caliciales. Beiheft zur Nova Hedwigia 79:597-713.

\section{Schmull M, Miadlikowska J, Pelzer M, Stocker-Wörgötter E, Hofstetter V,}

F. 2011. Phylogenetic affiliations of members of the heterogeneous lichenforming fungi of the genus Lecidea sensu Zahlbruckner (Lecanoromycetes, Ascomycota). Mycologia 103:983-1003.

53. Wedin M, Wiklund E, Jørgensen PM, Ekman S. 2009. Slippery when wet: phylogeny and character evolution in the gelatinous cyanobacterial lichens (Peltigerales, Ascomycetes). Molecular Phylogenetics and Evolution 53:862-871.

54. Otálora MAG, Aragón G, Molina MC, Martínez I, Lutzoni F. 2010.

Disentangling the Collema-Leptogium complex through a molecular phylogenetic study of the Collemataceae (Peltigerales, lichen-forming Ascomycota). Mycologia

55. Crespo A, Mattsson JE, Blanco O, Divakar PK, Lumbsch HT, Articus K, 102:279-290. 
three ribosomal markers and the nuclear RPB1 gene. Molecular Phylogenetics and Evolution 44:812-824.

769

770

56. Divakar PK, Crespo A, Wedin M, Leavitt SD, Hawksworth DH, Myllys L, McCune B, Randlane T, Bjerke JW, Ohmura Y, Schmitt I, Boluda CG, Alors D, Roca-Valiente B, Del-Prado R, Ruibal C, Buaruang K, Núñez-Zapata J, Amo de Paz G, Rico VJ, Molina MC, Elix JA, Esslinger TL, Tronstad IKK, Lindgren H, Ertz D, Gueidan C, Saag L, Mark K, Singh G, Dal Grande F, Parnmen S, Beck A, Navarro Benatti M, Blanchon D, Candan M, Clerc P, Goward T, Grube M, Hodkinson BP, Hur JS, Kantvilas G, Kirika PM, Lendemer J, Mattsson JE, Messuti MI, Miadlikowska J, Nelsen M, Ohlson JI, Pérez-Ortega S, Saag A, Sipman HJM, Sohrabi M, Thell A, Thor G, Truong C, Yahr R, Upreti DK, Cubas P, Lumbsch HT. 2015. Evolution of complex symbiotic relationships in a morphologically derived family of lichenforming fungi. New Phytologist 208:1217-1226.

57. Gaya E, Högnabba F, Holguin, Á, Molnar K, Fernández-Brime S, Stenroos S, Arup U, Søchting U, van den Boom P, Lücking R, Sipman HJM, Lutzoni F. 2012. Implementing a cumulative supermatrix approach for a comprehensive phylogenetic study of the Teloschistales (Pezizomycotina, Ascomycota). Molecular Phylogenetics and Evolution 63:374-387.

58. Arup U, Søchting U, Frödén P. 2013. A new taxonomy of the family Teloschistaceae. Nordic Journal of Botany 31:016-083.

59. Baloch E, Lücking R, Lumbsch HT, Wedin M. 2010. Major clades and phylogenetic relationships between lichenized and non-lichenized lineages in Ostropales (Ascomycota: Lecanoromycetes). Taxon 59:1483-1494. 
60. Resl P, Schneider K, Westberg M, Printzen C, Palice Z, Thor G, Fryday A, Mayrhofer H, Spribille T. 2015. Diagnostics for a troubled backbone: testing topological hypotheses of trapelioid lichenized fungi in a large-scale phylogeny of Ostropomycetidae (Lecanoromycetes). Fungal Diversity 73:239-258.

61. Miadlikowska J, Kauff F, Högnabba F, Oliver JC, Molnár K, Fraker E, Gaya E, Hafellner J, Hofstetter V, Gueidan C, Otálora MAG, Hodkinson B, Kukwa M, Lücking R, Björk C, Sipman HJM, Burgaz AR, Thell A, Passo A, Myllys L, Goward T, Fernández-Brimem S, Hestmark G, Lendemer J, Lumbsch HT, Schmull M, Schoch CL, Sérusiaux E, Maddison DR, Arnold AE, Lutzoni F, Stenroos S. 2014. A multigene phylogenetic synthesis for the class Lecanoromycetes (Ascomycota): 1307 fungi representing 1139 infrageneric taxa, 317 genera and 66 families. Molecular Phylogenetics and Evolution 79:132-

62. Lumbsch HT, Parnmen S, Kraichak E, Papong KB, Lücking R. 2014. High frequency of character transformations is phylogenetically structured within the lichenized fungal family Graphidaceae (Ascomycota: Ostropales). Systematics and Biodiversity 12:271-291.

63. Stenroos S, Laukka T, Huhtinen S, Döbbeler P, Myllys L, Syrjänen K,

809 Hyvönen J. 2010. Multiple origins of symbioses between ascomycetes and 810 bryophytes suggested by a five-gene phylogeny. Cladistics 26:281-300.

811 64. Leavitt SD, Grewe F, Widhelm T, Muggia L, Wray B, Lumbsch HT. 2016.

812 Resolving evolutionary relationships in lichen-forming fungi using diverse 813 phylogenomic datasets and analytical approaches. Scientific reports 6: 22262. 

S, Lee YH, Hur JS. 2013c. Agrobacterium tumefaciens-mediated transformation of the lichen fungus, Umbilicaria muehlenbergii. PLoS One 8:e83896.

66. Armaleo D, Sun X, Culberson C. 2011. Insights from the first putative

818 biosynthetic gene cluster for a lichen depside and depsidone. Mycologia 103:741819754.

67. Abdel-Hameed M, Bertrand RL, Piercey-Normore MD, Sorensen JL. 2016. Putative identification of the usnic acid biosynthetic gene cluster by de novo whole-genome sequencing of a lichen-forming fungus. Fungal Biol 120:306-316.

\section{Kampa A, Gagunashvili AN, Gulder TA, Morinaka BI, Daolio C,} product discovery in lichen provides evidence for a family of biosynthetic pathways in diverse symbioses. Proc Natl Acad SCI USA 110:E3129-3137.

69. McDonald TR, Dietrich FS, Lutzoni F. 2012. Multiple horizontal gene transfers of ammonium transporters/ammonia permeases from prokaryotes to eukaryotes: Toward a new functional and evolutionary classification. Mol Biol Evol 29:51-60.

70. McDonald TR, Mueller O, Dietrich FS, Lutzoni F. 2013. High-throughput genome sequencing of lichenizing fungi to assess gene loss in the ammonium transporter/ammonia permease gene family. BMC Genomics 14:1.

835 characterization of a full-length cDNA library from mycobiont of Endocarpon 836 pusillum (lichen-forming Ascomycota). World J Microbiol Biotechnol 27:28732837 . 
72. Wang YY, Zhang XY, Zhou QM, Zhang XL, Wei JC. 2015. Comparative transcriptome analysis of the lichen-forming fungus Endocarpon pusillum elucidates its drought adaptation mechanisms. Sci China Life Sci 57:89-100.

73. Miao VPW, Manoharan SS, Snæbjarnarson V, Andrésson ÓS. 2012.

$$
\text { Expression of lec-1, a mycobiont gene encoding a galectin-like protein in the }
$$
lichen Peltigera membranacea. Symbiosis 57:23-31.

74. Juntilla S, Rudd S. 2012. Characterization of a transcriptome from a non-model organism, Cladonia rangiferina, the grey reindeer lichen, using high-throughput next generation sequencing and EST sequence data. BMC Genomics 13:575.

75. Schneider T, Schmid E, de Castro JV, Cardinale M, Eberl L, Grube M, Berg G, Riedel K. 2011. Structure and function of the symbiosis partners of the lung lichen (Lobaria pulmonaria L. Hoffm.) analyzed by metaproteomics. Proteomics 11:2752-2756.

76. Junttila S, Laiho A, Gyenesei A, Rudd S. 2013. Whole transcriptome characterization of the effects of dehydration and rehydration on Cladonia rangiferina, the grey reindeer lichen. BMC Genomics 14:1.

77. Manoharan SS, Miao VPW, Andrésson ÓS. 2012. LEC-2, a highly variable lectin in the lichen Peltigera membranacea. Symbiosis 58:91-98.

78. Grube M, Cernava T, Soh J, Fuchs S, Aschenbrenner I, Lassek C, Wegner U, Becher D, Riedel K, Sensen CW, Berg G. 2015. Exploring functional contexts of symbiotic sustain within lichen-associated bacteria by comparative omics. International Society for Microbial Ecology J 9:412-424.

79. Kosugi M, Arita M, Shizuma R, Moriyama Y, Kashino Y, Koike H, Satoh K 2009. Responses to desiccation stress in lichens are different from those in their photobionts. Plant Cell Physiol 50:879-888. 
863

864

865

866

867

868

869

870

871

872

873

874

875

876

80. Meeßen J, Ott S. 2013. Recognition mechanisms during the precontact state of lichens: I. Mycobiont-photobiont interactions of the mycobiont of Fulgensia bracteata. Symbiosis 59:121-130.

81. Meeßen J, Epstein S, Ott S. 2013. Recognition mechanisms during the precontact state of lichens: II. Influence of algal exudates and ribitol on the response of the mycobiont of Fulgensia bracteata. Symbiosis 59:131-143.

82. Dietz S, Hartung W. 1999. The effect of abscisic acid on chlorophyll fluorescence in lichens under extreme water regimes. New Phytol 143:495-501.

83. Ott S, Krieg T, Spanier U, Schieleit P. 2000. Phytohormones in lichens with emphasis on ethylene biosynthesis and functional aspects on lichen symbiosis. Phyton 40:83-94.

84. Wang XY, Wei XL, Luo H, Kim JA, Jeon HS, Koh YJ, Hur JS. 2010. Plant hormones promote growth in lichen-forming fungi. Mycobiology 38:176-179.

85. Honegger R. 1991. Functional aspects of the lichen symbiosis. Annual Review of Plant Physiology and Plant Molecular Biology 42:553-578.

86. Honegger R. 2012. The symbiotic phenotype of lichen-forming ascomycetes and their endo- and epibionts, p 287-339. In Hock B (ed), The Mycota 9. Fungal Associations. 2nd ed. Springer, Berlin.

87. Rikkinen J. 2015. Cyanolichens. Biodiversity and Conservation 24:973-993.

88. James PW, Henssen A. 1976. The morphological and taxonomic significance of cephalodia. In DH Brown, DL Hawksworth \& RH Bailey (eds) Lichenology: Progress and Problems. Academic Press, London, pp. 27-77.

89. Hyvärinen M, Härdling R, Tuomi J. 2002. Cyanobacterial lichen symbiosis: the fungal partner as an optimal harvester. Oikos 98:498-504. 
90. Henskens FL, Green TGA, Wilkins A. 2012. Cyanolichens can have both cyanobacteria and green algae in a common layer as major contributors to photosynthesis. Annals of Botany 110:555-563.

91. Armaleo D, Clerc P, 1991. Lichen chimeras: DNA analysis suggests that one fungus forms two morphotypes. Experimental Mycology 15:1-10.

92. Magain N, Goffinet B, Sérusiaux E. 2012. Further photomorphs in the lichen family Lobariaceae from Reunion (Mascarene archipelago) with notes on the phylogeny of Dendriscocaulon cyanomorphs. Bryologist 115:243-254.

93. Thüs H, Muggia L, Pérez-Ortega S, Favero-Longo SE, Joneson S, O'Brien

$$
\text { H, Nelsen MP, Duque-Thüs R, Grube M, Friedl T, Brodie J, Andrew CJ, }
$$

Lücking R, Lutzoni F, Gueidan C. 2011. Revisiting photobiont diversity in the lichen family Verrucariaceae (Ascomycota). European Journal of Phycology 46:399-415.

94. Blaha J, Baloch E, Grube M. 2006. High photobiont diversity associated with the euryoecious lichen-forming ascomycete Lecanora rupicola (Lecanoraceae, Ascomycota). Biological Journal of the Linnean Society 88:283-293.

\section{Fernández-Mendoza F, Domaschke S, García MA, Jordan P, Martín MP,} Printzen C. 2011. Population structure of mycobionts and photobionts of the widespread lichen Cetraria aculeata. Molecular Ecology 20:1208-1232.

96. Rodriguez RJ, Henson J, Van Volkenburgh E, Hoy M, Wright L, Beckwith F, Kim Y-O, Redman RS. 2008. Stress tolerance in plants via habitat-adapted symbiosis. The ISME Journal 2:404-416.

97. Wedin M, Maier S, Fernandez-Brime S, Cronholm B, Westberg M, Grube M. 2016. Microbiome change by symbiontic invasion in lichens. Environmental Microbiology 18:1428-1439. 
98. Rikkinen J, Oksanen I, Lohtander K. 2002. Lichen guilds share related cyanobacterial symbionts. Science 297:357-357.

99. Rikkinen J. 2003. Ecological and evolutionary role of photobiont-mediated

915 guilds in lichens. Symbiosis 34:99-110.

916 100. Lawrey JD, Diederich P. 2003. Lichenicolous fungi: interactions, evolution, 917 and biodiversity. The Bryologist 106:80-120.

918 101. Petrini O, Hake U, Dreyfuss MM. 1990. An analysis of fungal communities 919 isolated from fruticose lichens. Mycologia 82:444-451.

920 102. Girlanda M, Isocrono D, Bianco C, Luppi-Mosca AM. 1997. Two foliose 921 lichens as microfungal ecological niches. Mycologia 89:531-536.

922 103. Prillinger H, Kraepelin G, Lopandic K, Schweigkofler W, Molnár O, 923 Weigang F, Dreyfuss MM. 1997. New species of Fellomyces isolated from 924 epiphytic lichen species. Systematic and Applied Microbiology 20:572-584.

925 104. Arnold AE, Miadlikowska J, Higgins KL, Sarvate SD, Gugger P, Way A, 926 Hofstetter V, Kauff F, Lutzoni F. 2009. A phylogenetic estimation of trophic 927 transition networks for ascomycetous fungi: are lichens cradles of symbiotrophic 928 fungal diversification? Systematic Biology 58:283-297.

929 105. Crittenden PD, David JC, Hawksworth DL, Campbell FS. 1995. Attempted 930 isolation and success in the culturing of a broad spectrum of lichen-forming and 931 lichenicolous fungi. New Phytologist 130:267-297

932 106. Fleischhacker A, Grube M, Kopun T, Hafellner J, Muggia L. 2015.

933 Community analyses uncover high diversity of lichenicolous fungi in alpine 934 habitats. Microbial Ecology 70:348-360. 
107. Zhang T, Wei XL, Zhang YQ, Liu HY, Yu LY. 2015. Diversity and distribution of lichen-associated fungi in the Ny-Ålesund Region (Svalbard, High Arctic) as revealed by 454 pyrosequencing. Scientific Reports 5:14850.

108. Werth S, Millanes AM, Wedin M, Scheidegger C. 2013. Lichenicolous fungi show population subdivision by host species but do not share population history with their hosts. Fungal Biology 117:71-84.

109. Millanes AM, Diederich P, Wedin M. 2016. Cyphobasidium gen. nov., a new lichen-inhabiting lineage in the Cystobasidiomycetes (Pucciniomycotina, Basidiomycota, Fungi). Fungal Biology, doi: 10.1016/j.funbio.2015.12.003.

110. Cardinale M, Puglia AM, Grube M. 2006. Molecular analysis of lichenassociated bacterial communities. FEMS Microbiology Ecology 57:484-495.

111. Grube M, Berg G. 2009. Microbial consortia of bacteria and fungi with focus on the lichen symbiosis. Fungal Biology Reviews 23:72-85.

112. Grube M, Cardinale M, de Castro JV, Müller H, Berg G. 2009. Speciesspecific structural and functional diversity of bacterial communities in lichen symbioses. The ISME Journal 3:1105-1115.

113. Hodkinson BP, Lutzoni F. 2009. A microbiotic survey of lichen-associated bacteria reveals a new lineage from the Rhizobiales. Symbiosis 49:163-180.

114. Selbmann L, Zucconi L, Ruisi S, Grube M, Cardinale M, Onofri S. 2010. Culturable bacteria associated with Antarctic lichens: affiliation and psychrotolerance. Polar Biology 33:71-83.

115. Bates ST, Cropsey GW, Caporaso JG, Knight R, Fierer N. 2011. Bacterial communities associated with the lichen symbiosis. Applied and Environmental Microbiology 77:1309-1314. 
116. Bjelland T, Grube M, Hoem S, Jorgensen SL, Daae FL, Thorseth IH, Øvreås L. 2011. Microbial metacommunities in the lichen-rock habitat. Environmental Microbiology Reports 3:434-442.

117. Mushegian AA, Peterson CN, Baker CC, Pringle A. 2011. Bacterial diversity across individual lichens. Applied and Environmental Microbiology 77: 42494252.

118. Hodkinson BP, Gottel NR, Schadt CW, Lutzoni F. 2012. Photoautotrophic symbiont and geography are major factors affecting highly structured and diverse bacterial communities in the lichen microbiome. Environmental Microbiology 14:147-161.

119. Cardinale M, de Castro JV, Müller H, Berg G, Grube M. 2008. In situ analysis of the bacterial community associated with the reindeer lichen Cladonia arbuscula reveals predominance of Alphaproteobacteria. FEMS Microbiology Ecology 66:63-71.

120. Erlacher A, Cernava T, Cardinale M, Soh J, Sensen CW, Grube M, Berg G. 2015. Rhizobiales as functional and endosymbiontic members in the lichen symbiosis of Lobaria pulmonaria L. Frontiers in microbiology 6.

121. Honegger R. 1992. Lichens: mycobiont-photobiont relationships, p. 225-275. In Reisser, W (ed) Algae and symbiosis. Biopress, Bristol.

122. Juntilla S. 2015. Characterisation of Cladonia rangiferina transcriptome and genome, and the effects of dehydration and rehydration on its gene expression. Ann Univ Turkensis, Doctoral thesis.

123. Park SY, Choi J, Kim JA, Jeong MH, Kim S, Lee YH, Hur JS. 2013a. Draft genome sequence of Cladonia macilenta KoLRI003786, a lichen-forming fungus producing biruloquinone. Genome Announc 1: e00695-13. 
985 YH, Hur JS. 2014a. Draft genome sequence of lichen-forming fungus Cladonia

986 metacorallifera strain KoLRI002260. Genome Announc 2: e01065-13.

987 125. Wang YY, Liu B, Zhang XY, Zhou QM, Zhang T, Li H, Yu YF, Zhang XL,

988 Hao XY, Wang M, Wang L, Wei JC. 2014. Genome characteristics reveal the

989 impact of lichenization on lichen-forming fungus Endocarpon pusillum Hedwig

990 (Verrucariales, Ascomycota). BMC Genomics 15:34.

991 126. Park SY, Choi J, Kim JA, Yu NH, Kim S, Kondratyuk SY, Lee YH, Hur JS.

992 2013b. Draft genome sequence of lichen-forming fungus Caloplaca

993 flavorubescens strain KoLRI002931. Genome Announc 1: e00678-13.

994 127. Park SY, Choi J, Lee GW, Jeong MH, Kim JA, Oh SO, Lee YH, Hur JS.

995 2014b. Draft genome sequence of Umbilicaria muehlenbergii KoLRILF000956, a

996 lichen-forming fungus amenable to genetic manipulation. Genome Announc

$997 \quad 2: \mathrm{e} 00357-14$.

998 
1000 Fig. 1. Diverse shapes of lichen thalli: A. Coral-like fruticose (shrub-like) thallus of

1001 Cladia retipora. Photo: Birgitta Strömbäck. B. Foliose (leaf-like) thalli of Lobaria

1002 pulmonaria and Lobarina scrobiculata covering the trunk of a Salix caprea in an old-

1003 growth spruce-dominated forest. Photo: Mats Wedin. C. Crustose (crust-like) thallus

1004 of Acarospora fuscata growing on a siliceous rock. Photo: Martin Westberg.

1005

1006 Fig. 2. Substantial biomass of lichens: A. Scandinavian costal lichen heath dominated 1007 by reindeer lichens (Cladonia spp.). Photo: Birgitta Strömbäck. B. Lichen-dominated 1008 soil crust community on the Great Alvar of Öland (Sweden). Photo: Martin Westberg.

1009 C. Abundant lichen cover dominated by Pseudocyphellaria homoeophylla, in a New

1010 Zeeland cool temperate rain forest. Photo: Birgitta Strömbäck.

1011

1012 Fig. 3. Vertical section through a thallus of Parmelia saxatilis, a foliose lichen. A

1013 distinct layer of green algal cells is clearly visible under the uppermost cortex; all

1014 other structures are made up by fungal hyphae. Photo: Einar Timdal.

1015

1016 Fig. 4. Vegetative dispersal in lichens: A. Soralia formed along the thallus margins in

1017 Vulpicida pinastri. These structures produce soredia, small granules of algal cells

1018 surrounded by fungal hyphae. Photo: Einar Timdal.B. Simple, cylindrical isidia

1019 formed on the thallus upper surface by Parmelia saxatilis. Photo: Einar Timdal.

1020

1021 Fig. 5. Optional lichenization: Schizoxylon albescens. A. Apothecium of a

1022 saprotrophic colony on dead aspen (Populus tremula) wood. Photo: Lucia Muggia. B. 
1023 Lichenized morph on aspen bark. Note the green algal colonies around the young

1024 apothecium. Photo: Lucia Muggia.

1025

1026 Fig. 6. A. Cephalodia visible as dark structures that include cyanobacteria, on

1027 Peltigera aphtosa. Photo: Einar Timdal. B. Phycosymbiodemes with different

1028 morphologies: Sticta with joined photomorphs. Note green-algal foliose parts growing

1029 out from the basal cyanobacterial fruticose parts. Photo: Mats Wedin.

1030

1031 Fig. 7. Symbiotic invasion: The transition of Cladonia thallus into Diploschistes

1032 thallus, by invasion of the latter. A. Uninfected Cladonia symphycarpa thallus. Photo:

1033 Einar Timdal. B. Cladonia thallus with clear Diploschistes infection (whitish areas)

1034 with typical Diploschistes apothecia (dark patches in the whitish areas). Photo: Einar

1035 Timdal. C. An almost complete take-over by Diploschistes, with only small remnants

1036 of Cladonia. Photo: Martin Westberg.

1037

1038

1039

1040 
1042 Table 1. Lichenized fungal species for which genome information is available (as of

1043 March 2016).

\begin{tabular}{|c|c|c|c|c|}
\hline Species & Class & $\begin{array}{l}\text { Genome size } \\
(\mathrm{Mb})\end{array}$ & $\begin{array}{l}\text { Gene } \\
\text { Number }\end{array}$ & Reference \\
\hline Acarospora strigata & Lecanoromycetes & 27 & $?$ & 70 \\
\hline Arthonia rubrocincta & Arthoniomycetes & 26 & $?$ & 70 \\
\hline Cladonia rangiferina & Lecanoromycetes & 32 & 9211 & 122 \\
\hline Cladonia grayi & Lecanoromycetes & 34 & $?$ & $\begin{array}{l}\text { Armaleo, } \\
\text { http://genome.jgi.doe.g } \\
\text { ov/Clagr2/Clagr2.home. } \\
\text { html }\end{array}$ \\
\hline Cladonia macilenta & Lecanoromycetes & 37,1 & 7322 & 123 \\
\hline Cladonia metacorallifera & Lecanoromycetes & 36,6 & 11361 & 124 \\
\hline Cladonia uncialis & Lecanoromycetes & 30 & $?$ & 67 \\
\hline Dibaeis baeomyces & Lecanoromycetes & 35 & $?$ & 70 \\
\hline Endocarpon pallidulum & Lecanoromycetes & 41 & $?$ & 70 \\
\hline Endocarpon pusillum & Lecanoromycetes & 37.5 & 9285 & 125 \\
\hline Graphis scripta & Lecanoromycetes & 36 & $?$ & 70 \\
\hline Gyalolechia flavorubescens & Lecanoromycetes & 34,4 & 9695 & 126 \\
\hline $\begin{array}{l}\text { Leptogium } \\
\text { austroamericanum }\end{array}$ & Lecanoromycetes & 46 & $?$ & 70 \\
\hline Peltula cylindrica & Lecanoromycetes & 32 & $?$ & 70 \\
\hline Physcia stellaris & Lecanoromycetes & 59 & $?$ & 70 \\
\hline Umbilicaria muehlenbergii & Lecanoromycetes & 34.8 & 8294 & 127 \\
\hline Xanthoria parietina & Lecanoromycetes & 32 & 10800 & Kuo et al., \\
\hline
\end{tabular}




\begin{tabular}{|l|l|l|l|l|}
\hline & & & & $\begin{array}{l}\text { http://genome.jgi.doe.g } \\
\text { ov/Xanpa1/Xanpa1.ho } \\
\text { me.html }\end{array}$ \\
\hline
\end{tabular}

1044

1045 